\title{
UPAYA PENANGGULANGAN TINDAK PIDANA PERDAGANGAN WANITA (TRAFFICKING IN WOMEN) OLEH PEMERINTAH KABUPATEN LAMPUNG TIMUR
}

Oleh:

\author{
MESTA WAHYU NITA \\ Dosen Institut Agama Islam Agus Salim Metro Lampung
}

\begin{abstract}
ABSTRAK
Kabupaten Lampung Timur merupakan kabupaten dimana masih banyak masyarakat yang memiliki tingakat ekonomi dan pendidikan yang rendah, sehingga banyak menjadi sasaran korban pedagangan orang. Upaya penanggulangan tindak pidana perdagangan wanita yang dilakukan oleh pemerintah Kabupaten Lampung Timur adalah upaya penanggulangan secara non penal yaitu dengan adanya dukungan program melalui Pendidikan Kecakapan Hidup, sosialisasi dan kampanye Pemberantasan Tindak Pidana Perdagangan Orang dan Eksploitasi Seksual Anak melalui media elektronik, media cetak, media tradisional, dan melalui komunitas. Faktor penghambat dalam upaya penanggulangan tindak pidana perdagangan wanita adalah adanya kesulitan dalam upaya penegakan hukumpidana tergadap pelaku perdagangan wanita karena bentuk kejahatannya yang tersembunyi dan terorganisir serta sulit melakukan pendataan terhadap jumlah korban, karena korban sendiri tidak mau melaporkan kejahatan yang dialaminya. Sehingga penegak hukum sulit untuk mencari alat bukti dari saksi/korban.

Penanggulangan tindak pidana perdangan wanita perlu adanya kerjasama yang lebih baik antara lembaga-lembaga yang berperan dalam penegakan hukum tindak pidana perdagangan wanita. Tidak hanya dalam upaya penanggulangan secara penal namun juga dalam upaya penaggulangan secara non penal. Serta dukungan masyarakat untuk ikut serta dalam upaya penanggulangan tindak pidana perdagangan wanita.
\end{abstract}

Kata kunci : Penanggulangan, Perdagangan Wanita, Lampung Timur 


\section{A. Pendahuluan}

Perdagangan orang di Indonesia pernah ada melalui perbudakan atau penghambaan. Dewasa ini perdagangan orang dianggap sama dengan perbudakan, yang diartikan sebagai suatu kondisi seseorang yang berada di bawah kepemilikan orang lain. Perbudakan adalah tindakan menempatkan seseorang dalam kekuasaan orang lain, sehingga orang tersebut tidak mampu menolak suatu pekerjaan yang secara melawan hukum diperintahkan orang lain kepadanya, walaupun orang tersebut tidak menghendakinya. ${ }^{1}$ Perdagangan orang merupakan masalah yang menjadi perhatian luas di Asia bahkan di seluruh dunia. Perdagangan orang terjadi tidak hanya menyangkut di dalam negeri Indonesia saja yaitu perdagangan orang antarpulau, tetapi juga perdagangan orang di luar negara Indonesia dimana terjadi perdagangan orang di negara-negara lain.

Perdagangan orang disini memfokuskan terhadap perdagangan wanita. Perdagangan wanita adalah semua usaha atau tindakan yang berkaitan dengan perekrutan, transportasi di dalam atau melintas perbatasan, pembelian, penjualan, transfer, pengiriman atau penerimaan seseorang dengan menggunakan penipuan atau tekanan termasuk penggunaan atau ancaman penggunaan kekerasan atau penyalahgunaan kekerasan atau lilitan utang dengan tujuan untuk mendapatkan atau menahan orang tersebut, baik dibayar atau tidak untuk kerja yang tidak diinginkan (domestik, seksual, atau reproduktif) dalam kerja paksa atau ikatan kerja atau dalam kondisi seperti perbudakan di dalam suatu lingkungan lain dari tempat dimana orang itu tinggal pada waktu penipuan, tekanan atau lilitan utang pertama kali.

Kenyataannya bahwa perempuan lebih dominan menjadi korban perdagangan orang karena perempuan dianggap paling rentan dan juga bahwa perempuan adalah kelompok strategis dari kebarlanjutan generasi karena perempuan mempunyai fungsi reproduksi dengan melahirkan keturunan. Korban biasanya ditipu, diberlakukan tidak manusiawi, dan dieksploitasi. Bentuk-bentuk eksploitasi itu sendiri di antaranya dengan cara memperlakukan korban untuk bekerja yang mengarah pada praktik-praktik eksploitasi seksual, perbudakan atau bentuk-bentuk perbudakan modern, perbuatan transplantasi organ tubuh untuk tujuan komersial, sampai penjualan bayi yang dimaksudkan untuk tujuan dan kepentingan mendapatkan keuntungan besar bagi para pelaku perdagangan orang. ${ }^{2}$

Hak asasi manusia merupakan hak-hak dasar atau hak-hak pokok yang dibawa manusia sejak lahir sebagai anugerah Tuhan Yang Maha Esa. Hak-hak asasi ini menjadi dasar daripada hak-hak dan kewajiban-kewajiban yang lain. Hak yang melekat pada manusia yaitu hak hidup dengan selamat, hak kebebasan, dan hak

${ }^{1}$ Henny Nuraeny, Tindak Pidana Perdagangan Orang Kebijakan Hukum Pidana dan Pencegahannya, ( Jakarta : Sinar Grafika, 2011), hlm. 27.

2 Farhana, Aspek Hukum Perdagangan Orang di Indonesia, (Jakarta : Sinar Grafika, 2010)

hlm. 4-5. 
kesamaan yang sifatnya tidak dapat dilanggar oleh siapapun juga. Untuk itu sudah menjadi kewajiban dari pemerintah atau Negara hukum untuk mengatur pelaksanaan hak-hak asasi ini yang berarti menjamin pelaksanaan, mengatur pembatasan-pembatasan demi kepentingan umum dan kepentingan bangsa dan Negara. ${ }^{3}$

Kasus perdagangan orang sangat kompleks, sehingga upaya pencegahannya maupun penaggulangan korban perdagangan orang harus dilakukan secara terpadu. Adapun faktor pendorong terjadinya perdagangan orang, antara lain meliputi kemiskinan, desakan kuat untuk bergaya hidup matrealistik, ketidakmampuan sistem pendidikan yang ada maupun masyarakat untuk mempertahankan anak supaya tidak putus sekolah dan melanjutkan kejanjang yang lebih tinggi serta petugas kelurahan atau kecamatan yang membuat pemalsuan KTP. Sebagian besar korban perdagangan orang berasal dari masyarakat golongan ekonomi rendah dalam tingkat pendidikan yang juga rendah. Hal ini disebabkan dalam perdagangan orang para pelaku kerap menipu para korbannya. Korban ditipu akan diberikan upah yang tinggi dan pekerjaan yang menyenangkan atau dipekerjakan di luar negeri. Akhirnya korban justru menjadi korban dari suatu sindikat perdagangan wanita atau buruh. ${ }^{4}$

Perdagangan orang di Kabupaten Lampung Timur bisa terjadi karena masih banyak masyarakat yang memiliki tingkat ekonomi dan pendidikan yang rendah, sehingga banyak menjadi sasaran korban pedagangan orang. Contohnya seperti kasus yang terjadi pada Winfaidah TKW yang berasal dari Lampung Timur. Winfaidah tidak menyadari bahwa dirinya menjadi korban dari perdagangan wanita. Winfaidah berangkat bekerja ke luar negeri dengan tujuan Singapura melalui PPTKIS (Perusahaan Penempatan Tenaga Kerja Indonesia Swasta). Winfaidah dianggap kurang mampu menguasai bahasa, maka dipulangkan kembali ke Batam. Oleh PPTKIS Winfidah dijual dan diberangkatkan ke Malaysia. Sesampainya di Malaysia Winfaidah disiksa oleh majikannya dan gajinya pun tidak pernah dibayarkan. Setelah puas menyiksa, majikan Winfaidah membuangnya ke jalan hingga ditemukan warga dan dilaporkan ke pihak yang berwajib.

Contoh kasus kedua yang dialami oleh Rur korban perdagangan orang yang berasal dari Lampung Timur. Awalnya Rur dijanjikan sebagai pembantu dan penyanyi disebuah kafe di Pangkal Pinang. Namun yang terjadi sebaliknya, Rur bersama belasan wanita dari berbagai daerah dipekerjakan disebuah hotel sebagai wanita penghibur. Namun jeratan hutang dan kebutuhan hidup yang semakin meningkat seolah-olah mengalahkan niat Rur untuk pulang. Kedua contoh kasus

\footnotetext{
${ }^{3}$ Undang-Undang Nomor 39 Tahun 1999 tentang Hak Asasi Manusia

${ }^{4}$ Ibid., hlm. 4.

5 http://radarlampung.co.id/read/radar/berita-foto/37065-winfaidah-tkw-lampungtimur-yang-kembali-berkumpul-dengan-keluargany diaskses pad tanggal 24 juni 2012 pukul 15:43 Wib.
} 
ini menunjukkan bahwa Kabupaten Lampung Timur merupakan daerah rawan terjadinya tindak pidana perdagangan orang. Masyarakat masih awam dengan tindak pidana perdangan orang sehingga korban biasanya tidak menyadari telah menjadi korban dari tindak pidana perdangan orang dan tidak melaporkan kasus tersebut kepada pihak yang berwajib, sehingga pelaku bisa dengan mudah lolos dari jerat hukum. ${ }^{6}$

Disamping kasus tersebut di atas, jumlah perdagangan wanita di Lampung Timur dapat dilihat dalam tabel berikut ini

\begin{tabular}{|c|c|c|c|c|c|c|}
\hline \multirow[b]{2}{*}{ No. } & \multirow[b]{2}{*}{$\begin{array}{l}\text { Korban Kejahatan } \\
\text { Terhadap Perempuan }\end{array}$} & \multicolumn{4}{|c|}{ Tah u n } & \multirow[b]{2}{*}{ Jumlah } \\
\hline & & 2009 & 2010 & 2011 & 2012 & \\
\hline 1. & KDRT & 3 & 7 & 4 & 2 & 16 \\
\hline 2. & Perkosaan & 10 & 7 & 3 & 1 & 21 \\
\hline 3. & Pelecehan seksual & 4 & 2 & 2 & 1 & 9 \\
\hline 4. & Penganiayaan & - & - & 2 & - & 2 \\
\hline 5. & Perdagangan Perempuan & 1 & - & - & - & 1 \\
\hline 6. & Penipuan Tenaga Kerja & 5 & 1 & 1 & 3 & 10 \\
\hline & J u m I a h & 23 & 17 & 12 & 7 & 59 \\
\hline
\end{tabular}

Sumber data : Data primer diperoleh dari Polres Lampung Timur, tahun 2012.

Pencegahan kejahatan pada dasarnya merupakan tujuan utama dari kebijakan kriminal. Mengingat kejahatan pedagangan orang bukan hanya menyangkut permasalahan moral, budaya dan Hak Asasi Manusia (HAM), tetapi juga masalah ekonomi, bisnis, dan hiburan (entertainment). Oleh karena itu dalam kebijakan penanggulangan kejahatan perdagangan orang khususnya wanita harus pula dapat menangkal dampak negatif dari masalah-masalah tersebut.

\section{B. Bentuk-Bentuk Perdagangan Orang}

\section{a. Pekerja Migran}

Dalam pelaksanaan penempatan TKI/TKW rentan terhadap tindak pidana perdagangan orang, lokasi kerentanan tersebut pada tahap berikut.

1) Proses rekrutmen, dimana calo-calo yang bekerja mengatasnamakan PPTKIS (Pelaksana Penempatan Tenaga Kerja Indonesia Swasta). Disinilah titik awal dari rangkaian penyalahgunaan kekuasaan yang sistematis berlangsung. Banyak ditemukan hal-hal yang merugikan TKI/TKW seperti pemotongan upah, pemalsuan identitas, dan pemalsuan kontrak kerja. Pemalsuan dokumen telah sering terjadi.

2) Tahap penampungan, penampungan adalah titik rawan yang berikutnya. Dalam kenyataan, rumah penampungan lebih menyerupai gudang tertutup. TKI/TKW tidak merasakan adanya persiapan pemberangkatan yang memadai, tidak ada kepastian berapa lama mereka menuggu

3) Tahap penempatan kerja, dengan proses rekrutmen menggunakan penipuan, pembujukan, pemalsuan, dan lain-lain serta proses pemberangkatan tanpa

${ }^{6}$ http://female.kompas.com/read/2009/04/18/08443228/perdagangan perempuan mereka mengaku terpojok. diakses pada tanggal 21 maret 2012. Pukul 10:43 Wib. 
orientasi yang memadai, maka banyak TKI/TKW mengalami kondisi kerentanan ditempat kerja. Kondisi itu anatara lain tempat dan kondisi kerja yang tidak sesuai dengan uraian dalam kontrak, termasuk jam kerja panjang, gaji lebih rendah atau tidak dibayarkan, tidak ada jaminan kesehatan, tidak ada hari libur, dipaksa memperpanjang masa kerja, sering mengalami kekerasan fisik dan mental ditempat kerja.

4) Proses kepulangan, dalam perjalanan pulang dari tempat kerja di luar negeri, TKI/TKW mengalami kerentanan lain dalam biaya pulang, pemerasan, dipaksa menukar mata uang asing dengan kurs rupiah yang amat rendah. ${ }^{7}$

\section{b. Pekerja Anak}

Pengertian pekerjaan terburuk untuk anak menurut Undang-Undang Nomor 1 Tahun 2000 tersebut di Indonesia secara umum meliputi anak-anak yang dieksploitasi secara fisik maupun ekonomi yang antara lain dalam bentuk berikut.

1) Anak-anak yang dilacurkan.

2) Anak-anak yang di pertambangkan.

3) Anak-anak yang bekerja sebagai penyelam mutiara.

4) Anak-anak yang bekerja disektor konstruksi.

5) Anak-anak yang bekerja di jermal.

6) Anak-anak yang bekerja sebagai pemulung sampah.

7) Anak-anak yang dilibatkan dalam produksi dan kegiatan yang menggunakan bahan-bahan peledak.

8) Anak-anak yang bekerja di jalan.

9) Anak-anak yang bekerja sebagai pembantu rumah tangga.

10) Anak-anak yang yang bekerja di industry rumah tangga.

11) Anak-anak yang bekerja diperkebunan.

12) Anak-anak yang bekerja pada penebangan, pengolahan, dan pengangkutan kayu.

13) Anak-anak yang bekerja pada industri dan jenis kegiatan yang menggunakan bahan kimia yang berbahaya. ${ }^{8}$

\section{c. Perdagangan Anak Melalui Adopsi (Pengangkatan Anak)}

Prosedur pengangkatan anak memang dilakukan secara ketat untuk melindungi hak-hak anak yang diangkat dan mencegah berbagai pelanggaran dan kejahatan seperti perdagangan anak. Ketidaktahuan prosedur ini menimbulkan persepsi di masyarakat bahwa mengadopsi anak itu mudah, sehingga sering kali masyarakat bertindak diluar hukum, maka dapat terjadi tindak pidana perdagangan anak. Berdasarkan Pasal 9 Ayat (1) Undang-Undang Nomor 23 Tahun 2002 tentang Perlindungan Anak, bahwa pengangkatan anak hanya dapat dilakukan untuk kepentingan yang terbaik bagi anak. Prinsip ini juga dianut dalam UndangUndang Nomor 12 Tahun 2006 tentang Kewarganegaraan RI. Adapun Pasal 39

\footnotetext{
7 Ibid., hlm. 37.

8 Ibid., hlm. 39.
} 
Ayat (2) Undang-Undang Nomor 23 Tahun 2002 tetang Perlindungan Anak Pasal 39 menjelaskan bahwa pengangkatan anak tidak memutuskan hubungan darah antara anak yang diangkat dengan orang tua kandungnya, selanjutnya Ayat (3) disebutkan bahwa calon orang tua angkat harus seagama dengan agama yang dianut oleh calon anak angkat dan apabila asal usul anak tidak diketahui, maka agama anak disesuaikan dengan agama mayoritas penduduk setempat menurut Ayat (5). Hal ini mencegah terjadinya pengangkatan anak yang berbeda agama, sehingga tidak terjadi benturan kewenangan antara Pengadilan Agama dan Pengadilan Negeri. Ayat (4) disebutkan bahwa pengangkatan anak oleh warga negara asing hanya dapat dilakukan sebagai upaya terakhir dan orang tua angkat wajib memberitahukan kepada anak angkatnya mengenai asal usulnya dan orang tua kandungnya, hal ini disebutkan dalam Pasal 40 Ayat (1). ${ }^{9}$

\section{d. Pernikahan dan Pengantin Pesanan}

Salah satu modus operandi perdagangan orang yang lain adalah pengantin pesanan (Mail Order Bride) yang merupakan pernikahan paksa dimana pernikahannya diatur oleh orang tua. Perkawinan pesanan ini menjadi perdagangan orang apabila terjadi eksploitasi baik secara seksual maupun ekonomi melalui penipuan, penyengsaraan, penahanan dokumen, sehingga tidak dapat melepaskan diri dari eksploitasi, serta ditutupnya akses informasi dan komunikasi dengan keluarga.

Ada dua bentuk perdagangan melalui perkawinan, yaitu

1) perkawinan digunakan sebagai jalan penipuan untuk mengambil perempuan tersebut dan membawa kewilayah lain yang sangat asing, namun sesampai di wilayah tujuan perempuan tersebut dimasukan dalam prostitusi.

2) perkawinan untuk memasukan perempuan kedalam rumah tangga untuk mengerjakan pekerjaan-pekerjaan domestik yang sangat eksploitatif bentuknya.

Fenomena pengantin pesanan ini banyak terjadi dalam masyarakat keturunan Cina di Kalimantan Barat dengan para suami berasal dari Taiwan walaupun dari Jawa Timur diberitakan telah terjadi beberapa kasus serupa. ${ }^{10}$

\section{Upaya Penanggulangan Tindak Pidana Perdagangan Wanita yang Dilakukan oleh pemerintah Kabupaten Lampung Timur}

Upaya atau kebijakan untuk melakukan pencegahan dan penanggulangan kejahatan termasuk dalam bidang kebijakan kriminal (criminal polici). ${ }^{11}$ Secara singkat dapat dikatakan bahwa tujuan akhir atau tujuan utama dari politik krimunal ialah "perlindungan masyarakat untuk mencapai kesejahteraan

\footnotetext{
9 Ibid., hlm. 47.

10 Ibid., hlm. 47-48.

11 Barda Nawawi Arief, Masalah Penegakan Hukum dan Kebijakan Penanggulangan Kejahatan, (Semarang : PT. Citra Aditya, 2000), hlm. 73.
} 
masyarakat". Penanggulangan terhadap tindak pidana perdagangan wanita dapat diartikan sebagai usaha rasional. Usaha-usaha yang rasional untuk menanggulangi kejahatan tidak hanya cukup dengan menggunakan sarana hukum pidana (penal), tetapi dapat juga menggunakan sarana-sarana non penal (sarana di luar hukum pidana).

\section{Upaya penal (dengan menggunakan sarana hukum pidana)}

Upaya penanggulangan tindak pidana perdagangan perempuan (trafficking in women) terhadap pelaku, kepolisian sebagai lembaga yang pertama kali yang harus dilalui dalam proses peradilan dengan menggunakan sarana penal. Polisi mempunyai tugas dan wewenang untuk melakukan serangkaian tindakan mulai dari penyidikan, penyelidikan kemudian dilanjutkan oleh kejaksaan dan pengadilan sampai adanya putusan hakim yang tetap.

Upaya penal dalam menanggulangi tindak pidan perdangan orang sudah diatur dalam beberapa peraturan hukum yang dapat menjerat para pelaku kejahatan antara lain tertuang dalam: Undang-Undang Republik Indonesia Nomor 1 Tahun 1946 tentang Kitab Undang-undang Hukum Pidana Pasal 324, Pasal 333 ayat (1, 2, 3, 4), Pasal 297. KUHP telah mengatur mengenai perdagangan perempuan dan anak di bawah umur, tetapi kurang efektif untuk menjerat pelaku perdagangan orang. Untuk itu dilahirkannya undang-undang khusus yang mengatur lebih jelas mengenai tindak pidana perdagangan orang. Perdagangan orang merupakan jaringan kejahatan yang terorganisir dan semakin meluas baik yang bersifat antarnegara, maupun dalam negeri, sehingga menjadi ancaman terhadap masyarakat, bangsa dan Negara serta penghormatan terhadap hak asasi manusia. Undangundang pemberantasan tindak rmencegah dan menanggulangi tindak pidana perdagangan orang yang disarankan pada komitmen nasional dan internasional untuk melakukan upaya pencegahan sejak dini, penindakan terhadap pelaku, perlindungan korban, dan peningkatan kerjasama. Selain itu peraturan perundangundangan yang mengatur tentang perdagangan orang belum memberikan landasan hukum yang menyeluruh dan terpadu bagi upaya pemberantasan tindak pidan perdagangan orang. ${ }^{12}$

Upaya penanggulangan tindak pidana perdagangan orang secara penal oleh pemerintah Kabupaten Lampung Timur sudah pernah dilakukan sampai tahap kepolisian, namun setelah dilakukan penyelidikan lebih lanjut kasus perdagangan wanita tersebut tidak masuk pada wilayah hukum kepolisian Lampung Timur melainkan pada kepolisian Lampung Selatan sehingga berkasnya dilimpahkan ke Polres Lampung Selatan.

\section{Upaya non penal (menggunakan sarana di luar hukum pidana)}

Upaya non penal dalam menanggulangi tindak pidana perdagangan orang dapat meliputi bidang yang sangat luas meliputi seluruh kebijakan sosial. Dimulai dari sosialisasi, pelatihan, hingga membuat posko pengaduan khusus untuk perempuan dan anak. Tujuan utama dari usaha-usaha non penal ditujukan untuk memperbaiki

12 Tjong Tjo Djung, op.cit., hlm. 35 
kondisi-kondisi sosial tertentu, yang secara tidak langsung mempunyai pengaruh preventif terhadap kejahatan. Hukum pidana/kebijakan hukum pidana mempunyai kedudukan yang sangat strategis bagi usaha penanggulangan kejahatan, yaitu dengan cara mengintegrasikan dan mengharmonisasikan seluruh kegiatan dalam suatu system hukum yang teratur dan terpadu. ${ }^{13}$

Berdasarkan hasil temuan dari penelitian ini menyatakan bahwa upaya penanggulangan tindak pidana perdagangan wanita dapat dilakukan dengan melaksanakan program Pusat Pelayanan Terpadu Pemberdayaan Perempuan dan Anak (P2TP2A). Pemberdayaan perempuan melakukan pendampingan kepada korban dari tindak pidana perdagangan orang mulai dari proses pelaporan, penyidikan, sampai dengan proses persidangan. Hal ini dilakukan untuk menjamin kesehatan, mental serta keamanan korban dari tekanan pelaku kejahatan ataupun dari keluarga dan masyarakat. Selain melakukan pendampingan, pemberdayaan perempuan juga melakukan sosialisasi dalam bentuk penyuluhan kepada masyarakat mengenai tindak pidana perdagangan perempuan. Pada tahun 2010 pemberdayaan perempuan melaksanakan sosialisasi sebanyak satu kali pada bulan November 2010 yang dilaksanakan di desa Siraman Kecamatan Pekalongan Kabupaten Lampung Timur. Soaialisasi tersebut diselenggarakan dengan Polres Lampung Timur, Rumah Sakit, serta Dinas Sosial Tenaga Kerja dan Transmigrasi Kabupaten Lampung Timur dan berperan sebagai narasumber.

Tahun 2011 Pemberdayaan Perempuan memprogramkan sosialisasi sebanyak tiga kali dan sudah terlaksana. Dalam setiap kali pertemuan dihadiri oleh 40 orang, yang berasal dari 4 kecamatan. Kecamatan-kecamatan tersebut antara lain yaitu : Kecamatan Sukadana, Marga Tiga, Sekampung, Batang Hari, Metro Kibang, Batang Hari Nuban, Raman Utara, Purbolinggo, Jepara, Sribawono, Labuhan Maringgai, Braja Selebah. Sebagai narasumber berasal dari Polres Lampung Timur dan Dinas Sosial Tenaga Kerja dan Transmigrasi. Pemberdayaan Perempuan berkordinasi dengan Guru Bimbingan Konseling serta penggerak PKK untuk membantu program sosialisasi mengenai tindak pidana perdagangan orang.

Sejauh ini upaya yang dilakukan masih dalam bentuk upaya-upaya non penal karena dalam kenyataannya belum pernah ada kasus perdagangan wanita yang sampai ke pengadilan Lampung Timur, sehingga upaya penanggulangannya dilakukan dalam bentuk non penal. ${ }^{14}$

Adanya kelemahan dalam masalah koordinasi juga dirasakan oleh perangkat daerah kabupaten. Sebagai contoh, dalam konteks pembuatan paspor untuk mereka yang akan berangkat keluar negeri seharusnya mendapat rekomendasi dari daerah asal korban. Namun meskipun daerah yang bersangkutan tidak memberikan rekomendasi ternyata korban yang bersangkutan dapat memperoleh paspor baik dari daerah lain atau bahkan dari Jakarta. Terkait dengan kasus semacam itu daerah merasa dirugikan karena ketika pembuatan paspor dan

\footnotetext{
${ }^{13}$ Henny Nuraeny, op.cit, hlm. 276.

${ }^{14}$ wawancaara dengan Sri Dwi Lastri Kusuma Ningsih selaku Kabid Pemberdaaan Perempuan Kabupaten Lampung Timur pada tanggal 28 mei 2012 di Lampung Timur
} 
pemberangkatan korban dilakukan oleh Jakarta, tapi ketika ada permasalahan maka korban trafficking tersebut diserahkan kepada daerah. Terkait dengan kasus seperti itu maka perlunya pembenahan dalam keimigrasian untuk lebih memudahkan pengawasan dan penanganan korban trafficking lintas negara. Dengan begitu perlu adanya koordinasi antar instansi dalam penanganan trafficking ini. ${ }^{15}$

Kelemahan dalam penanganan trafficking ini bukan terletak pada regulasi, karena berbagai regulasi yang dikeluarkan mulai dari tingkat pusat sampai ke daerah sudah memadai atau bahkan sudah optiomal, persoalannya justru pada tataran implementasi. Oleh karena itu yang perlu dilakukan adalah membangun kerja sama di antara berbagai lembaga dari tingkat pusat sampai daerah.

Berdasarkan hasil temuan dalam penelitian ini bahwa upaya penanggulangan kejahatan selain dapat dilakukan dengan upaya penal (represif) dapat juga dilakukan dengan upaya non penal (preventif). Upaya-upaya non penal tersebut dapat dilakukan dengan perencanaan kebijakan penanggulangan kejahatan, mengadakan kerja sama antar lembaga yang berwenang, melakukan upaya pencegahan dengan mengadakan sosialisasi terhadap bentuk-bentuk tindak kejahatan, serta mensosialisasikan peraturan perundang-undangan kepada masyarakat. Faktor ekonomi atau kemiskinan, tingkat pendidikan yang rendah, serta faktor lingkungan atau pengaruh modernisasi adalah faktor-faktor yang menyebabkan seseorang menjadi korban dari perdagangan orang. Untuk itu perlu adanya kerjasama antar lembaga yang berwenang dalam hal penanggulangan terhadap kejahatan perdagangan orang. Tidak hanya dari lembaga penegak hukumnya tetepi juga dari lembaga-lembaga terkait, seperti misalnya lembaga imigrasi, dinas sosial, pemberdayaan perempuan, dan lain sebagainya. ${ }^{16}$

\section{Simpulan}

Upaya penanggulangan tindak pidana perdagangan wanita yang dilakukan oleh pemerintah Kabupaten Lampung Timur dilakukan dengan upaya non penal dalam bentuk penanganan oleh Badan Pemberdayaan Perempuan dan Keluarga Berencana Kabupaten Lampung Timur adalah dengan adanya sosialisasi dalam bentuk penyuluhan yang dilakukan oleh Pemberdayaan Perempuan dengan di bantu oleh Dinas Tenaga Kerja dan Transmigrasi, Kepolisian, Rumah Sakit, Guru Bimbingan Konseling serta Pengerak PKK. Sosialisasi yang dilakukan 3(tiga) kali dalam setahun dalam setiap pertemuan dihadiri oleh 40 (empat puluh) orang dalam setiap kali pertemuan yang terdiri dari 4 (empat) kecamatan di wilayah Kabupaten Lampung Timur. Kecamatan-kecamatan yang sudah mengikuti sosialisasi diantaranya adalah Kecamatan Sukadana, Marga Tiga, Sekampung,

\footnotetext{
${ }^{15}$ wawancaara dengan Sri Dwi Lastri Kusuma Ningsih selaku Kabid Pemberdaaan Perempuan Kabupaten Lampung Timur pada tanggal 28 mei 2012 di Lampung Timur

${ }^{16}$ Wawancara dengan Edi Rifai selaku Dosen Hukum Pidana Universitas Lampung pada tanggal 18 juni 2012 di Fakultas Hukum Universitas Lampung
} 
Batang Hari, Metro Kibang, Batang Hari Nuban, Raman Utara, Purbolinggo, Jepara, Sribawono, Labuhan Maringgai, Braja Selebah.

Faktor-faktor yang menjadi penghambat dalam upaya penangulangan tindak pidana perdagangan wanita yaitu Kabupaten Lampung Timur merupakan Kabupaten yang memiliki wilayah yang luas menyebabkan sulit untuk mengumpulkan masyarakat untuk mengikuti kegiatan sosialisasi. Mata pencaharian sebagian besar masyarakat Kabupaten Lampung Timur adalah disektor pertanian dan perkebunan yang memiliki jam kerja yang tidak pasti, terkadang bisa bekerja hingga malam, sehingga bayak dari masyarakat yang tidak memiliki waktu untuk mengikuti kegiatan sosialisasi yang diadakan. Selain itu sulitnya mendapatkan berapa bnyak kasus yang sesungguhnya terjadi dikarenakan kasus perdagangan orang merupakan fenomena gunung es. Hal ini karena selain masih rendahnya kesadaran masyarakat tentang kejahatan perdagangan orang. Korban sendri terkadang tidak menyadari bahwa dirinya telah menjadi korban perdagangan orang. Selain itu juga kondisi korban yang tidak memungkinkan untuk melapor atas kasus yang dialaminya. Korban tidak melaporkan kasus yang dihadapi karena terkadang korban berada dalam ancaman, tidak tahu harus melapor ke mana, pertimbangan keluarga, gangguan psikis yang membuat korban selalu dalam ketakutan, menyalahkan diri, menutup diri, dan hilang kepercayaan diri, serta respon masyarakat dan lingkungan yang tidak mendukung korban.

\section{E. DAFTAR PUSTAKA}

\section{$\underline{\text { Buku-Buku }}$}

Arief, Barda Nawawi. 2008. Bunga Rampai Kebijakan Hukum Pidana. Kencana Media Group. Jakarta.

,2002. Bunga Rampai Kebijakan Hukum Pidana. PT. Citra Aditya. Bandung.

2005. Kebijakan Penegakan Dan Pengembangan Hukum Pidana. Citra Aditya Bhakti .Bandung.

2000. Masalah Penegakan Hukum dan Kebijakan Penanggulangan

Kejahatan.PT. Citra Aditya. Semarang.

Bentham, Jeremy. 1979, The Theory of Legislation diterjemahkan oleh Nurhadi.MA, 2006. (Teori Perundang Undangan.) .Penerbit Nusa Media. Bandung

Djung, Tjong Tjo. 2010. Analisis Pemidanaan Terhadap Pelaku Tindak Pidana Perdaganagn Orang. Universitas Lampung. Lampung. 
Djarksih, Gibson. 1996. Organisasi ; Pelaku, Struktur dan Proses . Erlangga. Jakarta.

Farhana.2010. Aspek Hukum Perdagangan Orang di Indonesia. Sinar Grafika. Jakarta.

Hamzah, Andi. 2004. Asas-Asas Hukum Pidana. PT Rineka Cipta. Jakarta.

Hamzah, Andi.1986. Hukum Pidana dan Acara Pidana,. Ghalia Indonesia. Jakarta.

Heru Permana, Is. 2007. Politik Kriminal. Penerbit Universitas Atma Jaya Yogyakarta. Yogyakarta.

Kamisa. 1997. Kamus Lengkap Bahasa Indonesia. Kartika. Surabaya.

Marzuki, Peter Mahmud. 2006. Penelitian Hukum. Kencana Prenada Media Group. Jakarta.

Muhammad, Abdulkadir, 2004. Hukum dan Penelitian Hukum. PT Citra Aditya Bakti. Bandung.

Nuraeny, Henny. 2011. Tindak Pidana Perdagangan Orang Kebijakan Hukum Pidana dan Pencegahannya. Sinar Grafika. Jakarta.

Syamsudin, M. 2007. Operasionalisasi Penelitian Hukum. PT Raja Grafindo Persada. Jakarta.

Thoha. 2003. Budaya Organisasi. Rosda karya Lawton. Yogyakarta.

Tutik, Titik Triwulan. 2006. Pengantar Ilmu Hukum..Prestasi Pustakarya.Jakarta

\section{Undang-Undang}

Undang-Undang Nomor 1 Tahun 1946 tentang Kitab Undang-Undang Hukum Pidana.

Undang-Undang Nomor 8 Tahun 1981 tenteng Hukum Acara Pidana.

Undang-Undang Nomor 21 Tahun 2007 tentang Tindak Pidana Perdagangan Orang (Trafficking).

Undang-Undang Nomor 23 Tahun 2002 tentang Perlindungan Anak. 


\section{Lain-lain}

Http://female.kompas.com/read/2009/04/18/08443228/perdagangan perempuan mereka mengaku terpojok. diakses pada tanggal 21 maret 2012. Pukul 10:43 Wib.

Http://setiya21.wordpress.com/2009/12/17/perilaku-organisasi/ diakses pada tanggal 24 juni 2012 pukul 14:52 Wib.

Http://www.hidayatullah.com/read/22609/11/05/2012/waspada!-tren-traffickingterus-meningkat.html diakses pada tanggal 24 juni 2012 pukul 15:05 Wib.

Http://radarlampung.co.id/read/radar/berita-foto/37065-winfaidah-tkw-lampungtimur-yang-kembali-berkumpul-dengan-keluargany diaskses pad tanggal 24 juni 2012 pukul 15:43 Wib. 